\title{
Kemampuan Pemecahan Masalah Matematis dan Self-Regulated Learning dengan Model Pembelajaran Learning Cycle $7 E$
}

\author{
Nita Putri Utami ${ }^{1}$, Rivdya Eliza ${ }^{2}$, Selvi Warahma ${ }^{3}$ \\ 1, 2,3 Program Studi Tadris Matematika, Fakultas Tarbiyah dan Keguruan, UIN IB Padang, \\ Jl. Prof. Mahmud Yunus Padang \\ nitautami@uinib.ac.id
}

\begin{abstract}
Class VIII students of MTsN 3 Solok Selatan have low mathematical problem-solving abilities and selfregulated learning (learning independence). This study aims to: 1) determine the mathematical problem-solving ability of students who study with the Learning Cycle 7E learning model with the mathematical problemsolving abilities of students who study with ordinary learning in class VIII MTsN 3 Solok Selatan. 2) knowing the self-regulated learning (independence of learning) mathematics of students who study with the Learning Cycle 7E learning model. Quasi-experimental research with Randomized Control Group Only Design. The results showed that 1) After testing the hypothesis with a t-test with $=0.05$ at a $95 \%$ confidence interval obtained t_count (2.26)> t_table (1.66), then the decision is $\mathrm{H} 0$ is rejected and $\mathrm{H} 1$ is accepted, meaning the ability The problem-solving ability of students who learn with the 7E Learning Cycle Model is higher than the problem-solving abilities of students who learn with ordinary learning. 2) self-regulated learning (independent learning) students who study with the 7E Learning Cycle model are categorized as good with a degree of achievement of $80.76 \%$.
\end{abstract}

Keywords: Mathematical Problem-solving, Self-Regulated Learning, Learning Cycle 7E

\begin{abstract}
Abstrak
Peserta didik kelas VIII MTsN 3 Solok Selatan memiliki kemampuan pemecahan masalah matematis dan selfregulated learning (kemandirian belajar) yang masih rendah. Penelitian ini bertujuan untuk:1)mengetahui kemampuan pemecahan masalah matematis peserta didik yang belajar dengan model pembelajaran Learning Cycle 7E dengan kemampuan pemecahan masalah matematis peserta didik yang belajar dengan pembelajaran biasa pada kelas VIII MTsN 3 Solok Selatan.2)mengetahui self-regulated learning (kemandirian belajar) matematika peserta didik yang belajar dengan model pembelajaran Learning Cycle 7E.Penelitian eksperimen semu dengan rancanganRandomized Control Group Only Design. Hasil penelitian menunjukkan bahwa 1) Setelah dilakukan uji hipotesis dengan uji-t dengan $\alpha=0,05$ pada selang kepercayaan $95 \%$ diperoleh $t \_$hitung $(2,26)>$ t-tabel $(1,66)$, maka keputusannya adalah H0ditolak dan H1 diterima artinya kemampuan pemecahan masalah peserta didik yang belajar dengan Model Learning Cycle 7E lebih tinggi daripada kemampuan pemecahan masalah peserta didik yang belajar dengan pembelajaran biasa. 2) self-regulated Learning (kemandirian belajar) peserta didik yang belajar dengan model Learning Cycle 7E dikategorikan baik dengan derajat pencapaian sebesar $80,76 \%$.
\end{abstract}

Kata kunci: Pemecahan Masalah Matematis, Self-Regulated Learning, Learning Cycle $7 E$

Copyright (c) 2022 Nita Putri Utami, Rivdya Eliza, Selvi Warahma

$\triangle$ Corresponding author: Nita Putri Utami

Email Address: nitautami@uinib.ac.id (Jl. Prof. Mahmud Yunus Padang)

Received 04 February 2022, Accepted 14 February 2022, Published 01 March 2022

\section{PENDAHULUAN}

Pendidikan merupakan suatu proses jangka panjang yang tidak dapat dipisahkan dari kehidupan manusia. Melalui pendidikan manusia dapat mengembangkan potensi yang dimilikinya. Dengan potensi tersebut manusia dapat memiliki ilmu sebagai bekal dalam menjalani kehidupannya di masa mendatang. Matematika merupakan salah satu mata pelajaran yang selalu kita temui dalam kehidupan sehari-hari dan matematika itu timbul karena pikiran-pikiran manusia yang berhubungan dengan ide,proses, dan penalaran (Lesi Istiqomah \& Husen Windayana, 2017). Tujuan pembelajaran matematika adalah untuk mengasah kemampuan bernalar, berfikir logis, dan sistematik dan agar 
peserta didik memiliki kemampuan pemecahan masalah (Sepriyanti, 2016). Hal ini menunjukkan bahwa kemampuan pemecahan masalah merupakan salah satu kemampuan yang penting dalam pembelajaran matematika. Akan tetapi, penelitian dan SIGI mengungkapkan bahwa peserta didik mempunyai kinerja yang kurang baik dalam matematika. Hasil PISA (Programme for International Students Assessmen) tahun 2018, pada kategori kemampuan matematika Indonesia menempati posisi 73 dari 79 negara partisipan dengan skor rata-rata 379. Sedangkan skor rata-rata Internasional yang ditetapkan adalah 500 (Hewi \& Shaleh, 2020). Maka diperlukan suatu solusi untuk memperbaiki rendahnya kemampuan pemecahan masalah. Kemampuan pemecahan masalah merupakan salah satu kemampuan yang esensial dan fundamental dalam pembelajaran matematika yang harus dimiliki oleh setiap siswa (Afidah \& Suhendar, 2020).

Selain kemampuan pemecahan masalah, dalam pembelajaran matematika juga diperlukan sikap self-regulated learning. Self-regulated learning adalah kemampuan siswa mengatur diri dalam belajar atau disebut juga kemandirian belajar siswa (Sumarmo, 2004). Kemampuan mengatur diri dalam belajar matematika berperan dalam meningkatkan kualitas dan kuantitas diri dalam belajar. Secara prinsipil, self- regulated menempatkan pentingnya kemampuan seseorang untuk mengatur dan mengendalikan diri sendiri, terutama dalam menghadaipi tugas sekolah. Self-regulated learning di Indonesia dikenal sebagai kemandirian belajar (Hafiziani Eka Putri dkk., 2020). Kemandirian peserta didik dalam belajar berperan penting bukan hanya mencapai prestasi belajar tetapi juga menekankan pada unsur untuk mengolah pengetahuannya sesuai dengan strategi yang mereka miliki (Hafiziani Eka Putri dkk., 2020). Pentingnya self-regulated learning (kemandirian belajar) dalam matematika juga didukung oleh hasil studi Hargis dengan temuannya yaitu: individu yang memiliki self-regulated learning (kemandirian belajar) yang tinggi cenderung belajar lebih baik, mampu memantau, mengevaluasi, dan mengatur belajarnya secara efektif, menghemat waktu dalam menyelesaikan tugasnya, mengatur belajar dan waktu secara efisien (Zamnah, 2019). Artinya peserta didik harus memiliki kemandirian belajar.

Learning cycle adalah model pembelajaran yang dirancang khusus untuk merangsang peserta didik mampu mengobservasi fenomena-fenomena yang terjadi di dunia, mampu mencari tahu suatu masalah, mampu memecahkan masalah tersebut, dan mencari masalah berbeda yang terjadi di tempat lain (Maryani, 2018). Learning cycle juga merupakan rangkaian tahap-tahap kegiatan yang diorganisasi sedemikian rupa sehingga peserta didik dapat menguasai kompetensi-kompotensi yang harus dicapai dalam pembelajaran dengan jalan berperan aktif (Mulana dkk., 2018). Ciri khas pembelajaran learning cycle adalah setiap peserta didik secara individu belajar materi pembelajaran yang sudah dipersiapkan oleh pendidik yang kemudian hasil belajar individual di bawa ke kelompok untuk didiskusikan bersama-sama atas keseluruhan jawaban (Khashan, 2016). Jadi, dapat disimpulkan bahwa learning cycle merupakan model pembelajaran inovatif yang mampu memfasilitasi peserta 
didik dalam mengkonstruksi pengetahuannya sendiri sehingga nanti akan dapat meningkatkan kemampuan pemecahan masalah peserta didik.

Adapun kelebihan penggunaan model learning cycle menurut Shoimin yaitu Model pembelajaran learning cycle $7 E$ ini terdiri atas 7 tahap yang dalam tahap-tahapnya berpusat pada peserta didik (student centered) dengan kegiatan yang memberikan dasar untuk observasi, pengumpulan data, analisis tentang kegiatan, peristiwa, dan fenomena sehingga peserta didik dapat menguasai kompetensi-kompetensi yang harus dicapai dalam pembelajaran dengan jalan berperan aktif pada tahap-tahap tersebut (Shoimin, 2014).

Menurut Eisenkraft (Unaenah \& Rahmah, 2019) tahap-tahap model pembelajaran Learning Cycle 7E meliputi: Elicit (memunculkan), Engage (melibatkan), Explore (menyelidiki), Explain (menjelaskan), Elaborate (menguraikan), Evaluate (menilai),dan Extend (memperluas). Kemampuan pemecahan masalah matematis peserta didik diharapkan dapat ditingkatkan melalui learning cycle 7E. Pada tahap elicit, pendidik mengungkapkan pemahaman awal peserta didik, lalu pada tahap engage, pendidik berusaha membangkitkan minat dan keingintahuan peserta didik tentang materi yang akan dipelajari, hal ini dapat dilakukan pendidik dengan mengaitkan materi pembelajaran pada kehidupan sehari-hari. Terkait dengan kemampuan pemecahan masalah, hal ini dapat membantu peserta didik dalam memahami atau mengidentifikasi masalah-masalah yang akan mereka hadapi. Lalu, peserta didik bekerja sama dalam kelompok-kelompok kecil tanpa pengajaran langsung dari pendidik di tahap explore, lalu tahap explain peserta didik menyimpulkan dan mengemukakan hasil temuannya dalam tahap explore. Pada tahap explore dan explain inilah peserta didik gunakan sebagai bekal dalam merencanakan pemecahan masalah.

Tahap elaborate, peserta didik secara kelompok, berlatih menerapkan konsep yang telah mereka peroleh sebelumnya untuk memecahkan masalah. Hal ini membantu peserta didik dalam menyelesaikan permasalahan yang dihadapi. Selanjutnya, pada tahap evaluate peserta didik dievaluasi pemahaman dan keterampilannya dengan mengerjakan kuis, dan terakhir pada tahap extend, peserta didik berfikir, mencari, menemukan dan menjelaskan contoh penerapan konsep yang telah dipelajari. Implementasi tahap evaluate dan extend dalam pemecahan masalah, peserta didik dapat mengecek kembali langkah-langkah yang telah dilakukan serta menginterpretasikan penyelesaian yang telah diperoleh pada tahap sebelumnya. Dengan demikian, penerapan model ini dalam pembelajaran matematika diharapkan dapat meningkatkan kemampuan peserta didik dalam memecahkan masalah..

Kemandirian belajar atau self-regulated learning diharapkan dapat dikembangkan melalui Learning Cycle 7E. Pada tahap elicit dan engage, dapat membantu peserta didik dalam membangkitkan rasa percaya diri. Pada tahap explore, explain, dan elaborate, diharapkan peserta didik dapat memiliki sikap percaya diri dan bertanggung jawab. Pada tahap evaluation dan extend peserta didik diharapkan dapat meningkatkan self-regulated learning terutama pada indikator percaya diri dan mampu bekerja sendiri 
Peneliti melakukan observasi pada saat pelaksanaan Praktek Pengalaman Lapangan (PPL) pada 07 September-18 November 2020 dan obeservasi pada 12-17 Februari 2021, serta hasil wawancara dengan pendidik matematika kelas VIII MTsN 3 Solok Selatan ditemukan banyak permasalahan dalam pembelajaran matematika diantaranya adalah pendidik masih banyak aktif dibandingkan peserta didik (teacher centered) dengan menerapkan pembelajaran biasa dan pelaksanaan pembelajaran belum menggunakan model-model variatif. Dalam proses pembelajaran pendidik mengawali pembelajaran dengan menjelasakan materi, dilanjutkan dengan mengerjakan soal-soal pada buku pegangan pendidik. Proses evaluasi pengerjaan soal yang dilakukan juga belum maksimal.

Rendahnya kemampuan pemecahan masalah peserta didik diketahui ketika pendidik memberikan latihan soal-soal non rutin, soal-soal cerita yang berisi masalah-masalah matematis, atau soal-soal yang tingkat kesulitannya lebih tinggi, hanya beberapa peserta didik saja yang mampu menyelesaikan soal tersebut dengan benar, sedangkan peserta didik yang lain masih mengalami kesulitan untuk menyelesaikannya.

Senada dengan uraian di atas, sulitnya peserta didik untuk memecahakan masalah matematis, terlihat dari jawaban peserta didik dalam ulangan harian yang mengujikan kemampuan pemecahan masalah materi luas dan keliling lingkaran. Salah satu soalnya adalah sebagai berikut:

Ibu akan membuat Pizza dengan ukuran yang berbeda. Ukuran Pizza yang besar berdiameter 16 $\mathrm{cm}$ dan ukuran yang sedang berdiameter $12 \mathrm{~cm}$. Kemudian, Ibu akan membuat alas Pizza dengan menggunakan kertas yang sesuai dengan ukuran Pizza. Bahan kertas mana yang lebih banyak diperlukan untuk membuat alas 1 Pizza ukuran besar atau alas 2 Pizza dengan ukuran sedang?

Berikut contoh pengerjaan soal oleh peserta didik.

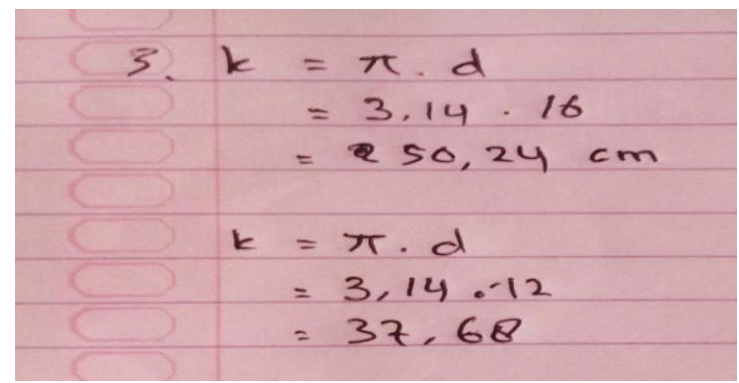

Gambar 1. Salah Satu Jawaban Peserta Didik Soal No.3

Terlihat pada Gambar 1, peserta didik tidak memahami bagaimana masalah yang disajikan, dan memberikan jawaban belum sistematis sesuai dengan menuliskan yang diketahui, yang ditanyan dan selanjutnya penyelesaian, tapi pada lembar jawaban peserta didik tidak melakukan hal itu. Peserta didik langsung saja menjawab pertanyaan yang diajukan. Hal ini membuat peserta didik tidak memahami maksud dari soal yang diberikan.

Pada langkah membuat perencanaan, peserta didik menggunakan rumus keliling lingkaran, seharusnya peserta didik menggunakan rumus luas lingkaran. Sehingga pada tahap menyelesaikan masalah, jawaban peserta didik tidak sesuai dengan yang diharapkan. Peserta didik tidak melakukan 
pengecekan kembali sehingga tidak menyadari bahwa jawaban yang dibuatnya tidak benar. Jawaban peserta didik seharusnya:

Diketahui $\quad$ : diameter alas pizza besar $=16 \mathrm{~cm}$, diameter alas pizza sedang $=12 \mathrm{~cm}$

Ditanya : alas pizza mana yang lebih banyak memerlukan kertas antara 1 pizza ukuran besar atau 2 pizza ukuran sedang?

Jawab :

$$
\begin{array}{ll}
\mathrm{r}_{\text {pizza besar }}=\frac{1}{2} \times d & =\frac{1}{2} \times 16=8 \mathrm{~cm} \\
\mathrm{~L}_{\text {pizza besar }} & =\pi \times r^{2} \\
& =3,14 \times 8 \times 8 \\
& =3,14 \times 64 \\
& =200,96 \mathrm{~cm}^{2} \\
& =\frac{1}{2} \times d=\frac{1}{2} \times 12=6 \mathrm{~cm} \\
\mathrm{r}_{\text {pizza sedang }} & =\pi \times r^{2} \\
\mathrm{~L}_{\text {pizza sedang }} & =3,14 \times 6 \times 6 \\
& =3,14 \times 36 \\
& =113,04 \mathrm{~cm}^{2}
\end{array}
$$

Alas kertas yang dibutuhkan 1 pizza besar $=1 \times 200,96=200,96$

$$
2 \text { pizza } \text { sedang }=2 \times 113,04=226,08
$$

Jadi, kertas yang lebih banyak digunakan untuk alas pizza adalah membuat 2 pizza sedang.

Berdasarkan hasil pengamatan pada lembar jawaban peserta didik, menunjukkan masih banyak indikator kemampuan pemecahan masalah yang belum dikuasai oleh peserta didik. Hal ini diduga karena peserta didik belum terbiasa mengerjakan soal kemampuan pemecahan masalah karena jarang diajarkan soal-soal yang mengasah kemampuan pemecahan masalah.

Selain rendahnya kemampuan pemecahan masalah matematis, peserta didik kelas VIII MTsN 3 Solok Selatan juga belum memiliki self-regulated learning (kemandirian belajar) sesuai yang diharapkan, seperti: saat proses pembelajaran berlangsung peserta didik kurang aktif dalam pembelajaran, dan malu bertanya jika ada hal yang belum dipahami. Saat pendidik mengajukan pertanyaan-pertanyaan atau meminta menuliskan jawaban latihan di papan tulis, hanya satu atau dua orang peserta didik yang menjawab pertanyaan pendidik ataupun mau menuliskan jawabannya. Hal ini mengindikasikan rendahnya rasa percaya diri peserta didik.

Selain itu, dalam latihan soal-soal yang diberikan terlihat bahwa banyak dari peserta didik yang mudah putus asa dalam menyelesaikan soal yang dianggap sulit, sehingga peserta didik hanya mengandalkan jawaban teman lain dengan mencontek atau menunggu penjelasan dari pendidik tanpa berusaha untuk menemukan sendiri jawabannya. Hal ini menunjukkan bahwa peserta didik belum mampu bekerja sendiri. 
Sikap bertanggung jawab peserta didik juga belum sesuai dengan yang diharapkan. Ditemukan bahwa ketika proses pembelajaran sudah dimulai, masih terdapat peserta didik yang terlambat. Saat proses pembelajaran berlangsung beberapa peserta didik tidak memperhatikan pendidik saat menerangkan pembelajaran di depan kelas. Saat diberikan tugas dan PR untuk dikerjakan di rumah pun banyak diantara peserta didik yang tidak mengerjakannya dengan alasan tidak mengerti, lupa, tidak sempat mengerjakannya dan lain sebagainya.

Dari beberapa uraian di atas terlihat bahwa masih rendahnya kemampuan pemecahan masalah matematis dan self-regulated learning peserta didik di MTsN 3 Solok Selatan. Keadaan ini berdampak pada hasil belajar peserta didik. Rendahnya hasil belajar peserta didik dapat dilihat dari hasil Ujian Tengah Semester II mata pelajaran matematika peserta didik kelas VIII MTsN 3 Solok Selatan Tahun Pelajaran 2020/2021 yang disajikan pada Tabel 1.

Tabel 1. Persentase Ketuntasan Nilai Ujian Tengah Semester Matematika

\begin{tabular}{|c|c|c|c|c|c|}
\hline \multirow{2}{*}{ Kelas } & \multirow{2}{*}{ Jml } & \multicolumn{2}{|c|}{ Tuntas $(\geq \mathbf{7 5})$} & \multicolumn{2}{c|}{ Tidak Tuntas $(<\mathbf{7 5})$} \\
\cline { 3 - 6 } & & Jml & $\%$ & Jml & $\%$ \\
\hline VIII.1 & 37 & 9 & 24,32 & 28 & 71,79 \\
\hline VIII.2 & 38 & 10 & 26,31 & 28 & 73,68 \\
\hline VIII.3 & 37 & 12 & 32,43 & 25 & 67,56 \\
\hline VIII.4 & 39 & 12 & 30,76 & 27 & 69,23 \\
\hline VIII.5 & 37 & 8 & 21,62 & 29 & 78,37 \\
\hline & $\mathbf{1 8 8}$ & $\mathbf{5 1}$ & $\mathbf{2 7 , 1 2}$ & $\mathbf{1 3 7}$ & $\mathbf{7 2 , 8 7}$ \\
\hline
\end{tabular}

Sumber: Pendidik matematika kelas VIII MTsN 3 Solok Selatan

Tabel 1 memperlihatkan bahwa persentase yang tuntas lebih rendah dibandingkan yang tidak tuntas. Hasil belajar yang dicapai peserta didik masih dibawah Kriteria Ketuntasan Minimal (KKM) yang ditetapkan sekolah yaitu 75. Hal ini memperlihatkan bahwa hasil belajar peserta didik masih rendah.

Salah satu cara memperbaiki rendahnya kemampuan pemecahan masalah dan kemandirian belajar peserta didik adalah dengan menggunakan pendekatan pembelajaran yang lebih mendukung aktivitas peserta didik dalam memahami suatu materi dan lebih menekankan peserta didik berperan aktif dalam pembelajaran. Pendekatan pembelajaran yang efektif dan diperkirakan dapat meningkatkan kemampuan pemecahan masalah dan kemandirian belajar peserta didik adalah model yang berparadigma konstruktivisme, salah satunya adalah model Learning Cycle 7E.

\section{METODE}

Jenis penelitian ini merupakan eksperimen semu dengan Randomized Control Group Only Design sebagai rancangan penelitian.

Tabel 2. Rancangan Penelitian

\begin{tabular}{|c|c|c|}
\hline Kelas & Perlakuan & Tes Akhir \\
\hline Eksperimen & $\mathrm{X}$ & $\mathrm{T}$ \\
\hline Kontrol & - & $\mathrm{T}$ \\
\hline
\end{tabular}


MTsN 3 Solok Selatan sebagai tempat penelitian dan dilakukan terhadap 1peserta didik kelas VIII semester genap tahun pelajaran 2020/2021. Penelitian ini dilaksanakan dari tanggal 22 Mei 2021 sampai 07 Juni 2021. Peserta didik kelas VIII MTsN 3 Solok Selatan Tahun Pelajaran 2020/2021 yang terdiri dari 5 kelas, dengan jumlah peserta didik 188 orang merupakan populasi. Setelah melakukan uji statistik terhadap populasi dan memenuhi ketentuan pengambilan sampel secara acak diperoleh dua kelas secara acak yaitu kelas VIII.3 sebagai kelas eksperimen dan kelas VIII.1 sebagai kelas kontrol.

Untuk menguji hipotesis digunakan uji-t. Sebelum melakukan uji hipotesis terlebih dahulu dilakukan uji normalitas terhadap data sampel.

1. Uji Normalitas

Uji normalitas bertujuan untuk melihat apakah data sampel berdistribusi normal atau tidak. Uji yang digunakan adalah uji Liliefors.

2. Uji Homogenitas Variansi

Pengujian ini bertujuan untuk melihat apakah kedua kelas mempunyai variansi yang homogen atau tidak. Pengujian ini dilakukan dengan menggunakan uji $F$. Jika $F_{\text {hitung }}<F_{\text {tabel }}$ berarti data kelas sampel mempunyai variansi yang homogen, sebaliknya jika $F_{\text {hitung }}>F_{\text {tabel }}$ berarti data kelas sampel tidak mempunyai variansi yang homogen.

3. Uji hipotesis

Uji hipotesis bertujuan untuk membuktikan apakah kemampuan pemecahan masalah matematis peserta didik kelas eksperimen lebih tinggi daripada kelas kontrol. Sampel berdistribusi normal dengan variansi yang homogen, maka digunakan rumus:

$t=\frac{\overline{X_{1}}-\overline{X_{2}}}{\sqrt[S]{\frac{1}{n_{1}}+\frac{1}{n_{2}}}}$

Dengan,

$S^{2}=\frac{\left(n_{1}-1\right) s_{1}^{2}+\left(n_{2}-1\right) s_{2}^{2}}{n_{1}+n_{2}-2}$

Keterangan:

$\overline{X_{1}}=$ Skor rata-rata hasil tes kelas eksperimen

$\overline{X_{2}}=$ Skor rata-rata hasil tes kelas kontrol

$s=$ Simpangan baku gabungan

$n_{1}=$ Jumlah peserta didik kelas eksperimen

$n_{2}=$ Jumlah peserta didik kelas kontrol

$s_{1}=$ Simpangan baku kelas eksperimen

$s_{2}=$ Simpangan baku kelas kontrol

Formulasi statistik hipotesis yang akan diuji adalah sebagai berikut:

$\mathrm{H}_{0}: \mu 1 \leq \mu 2$

$\mathrm{H}_{1}: \mu 1>\mu 2$ 
Kriteria pengujian hipotesis adalah: $\mathrm{H}_{0}$ diterima jika $t_{\text {hitung }} \leq t_{\text {tabel }}$, dengan $d f=n_{1}+n_{2}-2$ dengan peluang (1- $\alpha$ ). $\mathrm{H}_{0}$ ditolak jika $t_{\text {hitung }}>t_{\text {tabel }}$, dengan $d f=n_{1}+n_{2}-2$ dengan peluang (1$\alpha)$.

\section{HASIL DAN DISKUSI}

\section{Tes Kemampuan Pemecahan Masalah Matematis}

Hasil penelitian pada kelasVIII.3 sebagai kelas eksperimen yang belajar dengan model pembelajaran Learning Cycle $7 E$ diikuti oleh 37 peserta didik. Pembelajaran yang sering digunakan guru diterapkan pada Kelas VIII.1 sebagai kelas kontrol diikuti oleh 37 peserta didik. Berdasarkan hasil tes dapat dibuat rincian seperti dalam Tabel 3 berikut.

Tabel 3. Statistik Deskriptif Hasil Tes Kemampuan Pemecahan Masalah Matematis

\begin{tabular}{|c|c|c|c|c|c|c|}
\hline Kelas & $\mathbf{N}$ & $\overline{\boldsymbol{x}}$ & $\boldsymbol{x}_{\max }$ & $\boldsymbol{x}_{\min }$ & $\boldsymbol{s}_{\boldsymbol{i}}$ & $\boldsymbol{S}_{\boldsymbol{i}}{ }^{2}$ \\
\hline Eksp & 37 & 73,43 & 88,53 & 54,17 & 9,19 & 84,37 \\
\hline Ktrl & 37 & 68,19 & 85,42 & 46,88 & 10,80 & 116,55 \\
\hline
\end{tabular}

Dapat dilihat bahwa pada kelas eksperimen rata-rata nilai akhir peserta didik adalah 73,43 , sedangkan rata-rata nilai pada kelas kontrol adalah 68,19. Artinya lebih tinggi rata-rata kelas ekperimen dibandingkan kelas kontrol. Simpangan baku kelas eksperimen lebih rendah dari pada kelas kontrol yaitu 9,19 pada kelas eksperimen dan 10,80 pada kelas kontrol. Hal ini menunjukkan bahwa nilai pada kelas eksperimen lebih seragam dan lebih baik dari pada kelas kontrol. Kesimpulan yang diperoleh bahwa Model Pembelajaran Learning Cycle $7 E$ efektif ditinjau dari kemampuan pemecahan masalah matematis peserta didik.

Data tes kemampuan pemecahan masalah matematis peserta didik kelas sampel lebih rinci dapat dilihat melalui masing-masing item soal tes sesuai dengan indikator kemampuan pemecahan masalah matematis. Rincian penilaian perindikator dapat dilihat pada Tabel 4 berikut.

Tabel 4. Nilai Rata-rata Peserta Didik Setiap Indikator Kemampuan Pemecahan Masalah

\begin{tabular}{|c|c|c|c|}
\hline No & Indikator & Eksp & Kontrol \\
\hline 1 & Memahami masalah & 92,34 & 88,74 \\
\hline 2 & Menyusun rencana pemecahan masalah & 71,85 & 68,24 \\
\hline 3 & $\begin{array}{l}\text { Melaksanakan rencana penyelesaian } \\
\text { masalah }\end{array}$ & 65,88 & 61,15 \\
\hline 4 & Melakukan pengecekan kembali & 63,63 & 54,62 \\
\hline \multicolumn{2}{|c|}{ Jumlah } & 293,70 & 272,75 \\
\hline & Rata-rata & 73,43 & 68,19 \\
\hline
\end{tabular}

Berdasarkan Tabel 4 dapat dilihat rata-rata skor setiap indikator kemampuan pemecahan masalah matematis untuk kelas eksperimen dan kelas kontrol. Rata-rata skor untuk setiap indikator pemecahan masalah matematis kelas eksperimen lebih tinggi daripada kelas kontrol. Hal ini menunjukkan bahwa kemampuan pemecahan masalah matematis peserta didik kelas eksperimen yang 
belajar dengan model pembelajaran Learning Cycle $7 E$ lebih tinggi daripada kemampuan pemecahan masalah matematis peserta didik pada kelas kontrol yang belajar dengan pembelajaran biasa.

\section{Angket Self-Regulated Learning (Kemandirian Belajar)}

Setelah menghitung perolehan skor kemandirian belajar matematika peserta didik pada masing-masing indikator, maka hasil akhir perhitungan skor Self-Regulated Learning (kemandirian belajar) matematika tiap indikator dari 37 peserta didik terhadap pembelajaran matematika secara keseluruhan dapat dilihat pada Tabel 5.

Tabel 5. Hasil Akhir Perhitungan Nilai Setiap Indikator Kemandirian Belajar Matematika Peserta Didik Kelas Eksperimen

\begin{tabular}{|c|c|c|c|c|}
\hline Indikator & $\begin{array}{c}\text { No. Pernyataan } \\
\text { Angket }\end{array}$ & $\begin{array}{c}\text { Rata- } \\
\text { rata }\end{array}$ & $\begin{array}{c}\text { Derajat Pencapaian } \\
(\mathbf{\%})\end{array}$ & Kriteria \\
\hline Bertang-gung jawab & $1-8$ & 4,17 & 83,45 & Baik \\
\hline Percaya Diri & $9-16$ & 3,91 & 78,18 & Cukup \\
\hline $\begin{array}{c}\text { Mampu Bekerja } \\
\text { Sendiri }\end{array}$ & $17-22$ & 4,03 & 80,63 & Baik \\
\hline \multicolumn{2}{|c|}{ Total } & 4,04 & 80,76 & Baik \\
\hline
\end{tabular}

Tabel 5 di atas menjelaskan bahwa indikator pertama kemandirian belajar peserta didik yaitu bertanggung jawab memperoleh persentase pencapaian pada indikator tersebut adalah 83,45\% dengan kriteria baik. Indikator kedua yaitu percaya diri dengan persentase pencapain adalah 78,18\% dengan kriteria cukup. Dan indikator ketiga yaitu mampu bekerja sendiri dengan persentase pencapain adalah 80,63\% dengan kriteria baik. Dari tabel 5 di atas dijelaskan bahwa secara keseluruhan self-regulated learning (kemandirian belajar) matematika peserta didik untuk setiap indikator dalam pembelajaran matematika memperoleh persentase pencapai $80,76 \%$ dengan kriteria baik.

Selanjutnya untuk memperoleh kesimpulan tentang data hasil kemampuan pemecahan masalah matematis dan self-regulated learning (kemandirian belajar) peserta didik dilakukan analisis secara statistik.

\section{Hasil Uji Normalitas}

Berdasarakan hasil uji normalitas dengan Software SPSS yang dilakukan terhadap kelas kontrol dan kelas eksperimen, maka didapatkan kesimpulan sebagaimana yang terdapat pada Tabel 6 .

Tabel 6. Hasil Analisis Uji Normalitas Sampel dengan SPSS

\begin{tabular}{|c|c|c|c|c|c|c|c|}
\hline \multirow{2}{*}{} & \multirow{2}{*}{ Kelas } & \multicolumn{3}{|c|}{ Kolmogorov-Smirnov $^{\mathrm{a}}$} & \multicolumn{3}{c|}{ Shapiro-Wilk } \\
\cline { 3 - 8 } & & Statistic & Df & Sig. & Statistic & Df & Sig. \\
\hline \multirow{2}{*}{ Nilai } & Eks & .109 & 37 & $.200^{*}$ & .965 & 37 & .281 \\
\cline { 2 - 8 } & Ktrl & .129 & 37 & .125 & .949 & 37 & .088 \\
\hline
\end{tabular}

*. This is a lower bound of the true significance.

a. Liliefors Significance Correction

Berdasarkan Tabel 6 dapat dilihat bahwa keseluruhan kelas sampel mempunyai tingkat signifikan $>0,05$. Hal ini berarti kedua kelas sampel berdistribusi normal. 


\section{Hasil Uji Homogenitas}

Data kelas sampel telah diperoleh berdistribusi normal dilanjutkan dengan uji homogenitasdengan bantuan sofware SPSS. Tabel 6 menunjukkan nilai probabilitas (signifikan) $0,186>0,05$. Artinya, sampel mempunyai variansi yang homogen.

\section{Tabel 6. Hasil Analisis Uji Homogenitas Sampel Dengan SPSS}

\begin{tabular}{|c|c|c|c|}
\hline \multicolumn{4}{|l|}{ Nilai } \\
\hline Levene Statistic & df1 & df2 & Sig. \\
\hline 1.780 & 1 & 72 & .186 \\
\hline
\end{tabular}

\section{Hasil Uji Hipotesis}

Uji hipotesis dilakukan dengan menggunakan uji-t. Dengan $\alpha=0.05$ dan $d f=72$ diperoleh $t_{\text {tabel }}=1,66$. Berdasarkan perbandingan diperoleh $t_{\text {hitung }}>t_{\text {tabel }}(2,26>1,66)$. Artinya, $H_{0}$ ditolak atau kemampuan pemecahan masalah matematis peserta didik yang belajar dengan model pembelajaran Learning Cycle $7 E$ lebih tinggi dari pada kemampuan pemecahan masalah matematis peserta didik yang belajar dengan pembelajaran biasa di kelas VIII MTsN 3 Solok Selatan tahun pelajaran 2020/2021.

Berdasarkan hasil deskripsi data dan analsis data diperoleh kemampuan pemecahan masalah matematis peserta didik pada kelas eksperimen lebih tinggi dari pada kemampuan pemecahan masalah matematis peserta didik kelas kontrol. Halini dikarenakan perbedaan perlakuan yang diberikan pada kelas eksperimen yang belajar dengan model pembelajaran Learning Cycle $7 E$, sedangkan kelas kontrol yang belajar dengan pembelajaran biasa.

Proses pembelajaran yang menggunakan model pembelajaran Learning Cycle $7 E$, dapat meningkatkan kemampuan pemecahan masalah matematis peserta didik dan menumbuhkan selfregulated learning (kemandirian belajar) peserta didik. Berikut dijelaskan secara lebih rinci mengenai kemampuan pemecahan masalah matematis dan self-regulated learning (kemandirian belajar) peserta didik dalam mencapai setiap indikator kemampuan pemecahan masalah matematis dan self-regulated learning (kemandirian belajar) yang diberikan.

Pada fase elicit, pendidik memunculkan pengetahuan awal peserta didik yang terkait dengan materi yang akan dipelajari, dalam fase ini peserta didik diberikan beberapa pertanyaan oleh pendidik, lalu peserta didik menjawab pertanyaan pendidik berdasarkan konsep yang diketahui. Pada fase elicit indikator memahami masalah dan menumbuhkan self-regulated learning (kemandirian belajar) pada aspek percaya diri dapat ditingkatkan atau dikembangkan dengan baik.

Fase selanjutnya yaitu Engange, pada fase ini pendidik berusaha membangkitkan minat dan rasa ingin tahu peserta didik melalui kegiatan mengamati LKPD yang berisikan permasalahan. Pendidik mengarahkan peserta didik untuk mengajukan pertanyaan tentang yang diamatinya. Pertanyaan yang diajukan merupakan pertanyaan yang memiliki keterkaitan dengan materi yang akan dipelajari. Pada fase ini dapat meningkatkan indikator memahami masalah dan menumbuhkan selfregulated learning (kemandirian belajar) pada aspek percaya diri. 
Tahap berikutnya adalah Fase Explore, pada fase ini pendidik membagi kelompok yang terdiri dari 4-5 orang peserta didik secara heterogen. Peserta didik saling mengeluarkan pendapat dan dituntut untuk menyelesaikan permasalahan yang disajikan pada LKPD, sehingga peserta dengan kegiatan berdiskusi kelompok ini peserta didik dapat menyelesaikan masalah dengan baik. Hal ini sejalan dengan pendapat Suherman dengan mengelompokkan peserta didik ke dalam kelompokkelompok kecil memberi peluang untuk mendiskusikan masalah yang dihadapi, saling tukar ide antar peserta didik, dan mendiskusikan alternatif pemecahan masalah. Selain itu, peserta didik dimungkinkan mampu menyelesaikan masalah yang lebih baik dibanding jika mereka bekerja sendiri (Suherman, 2003). Hal ini membantu peserta didik dalam menyusun rencana penyelesain masalah. Selanjutnya Darr \& Fisher mengatakan bahwa agar peserta didik mandiri, peserta didik perlu diberi kesempatan berpikir, mengamati, dan mengikuti pikiran orang lain (Darr \& Fisher, 2015). Dan selanjutnya di dukung oleh Shoimin bahwa, ciri khas model pembelajaran learning cycle ini adalah semua anggota kelompok bertanggung jawab secara bersama-sama atas keseluruhan jawaban (Shoimin, 2014). Sehingga dapat disimpulkan tahap ini dapat membentuk sikap self-regulated learning (kemandirian belajar) peserta didik terutama sikap percaya diri dan tanggung jawab.

Fase Explain, pada tahap ini, peserta didik menyimpulkan dan mengemukakan hasil temuannya dalam tahap explore. Sedangkan peserta didik lain mendengarkan, menanggapi dan menganalisa pemaparan dari kelompok yang persentasi. Dengan kegiatan menyimpulkan dan mengemukakan hasil temuannya, peserta didik dapat mengetahui bagaimana strategi yang tepat untuk dipilih peserta didik dalam menyelesaikan masalah. Sehingga pada fase ini juga membantu dalam meningkatkan kemampuan pemecahan masalah matematis peserta didik pada tahap menyusun rencana pemecahan masalah dan mengasah kemandirian belajar peserta didik pada aspek bertanggung jawab dan percaya diri.

Fase Elaborate, peserta didik kembali berdiskusi bersama dalam kelompok untuk menyelesaiakan soal-soal latihan pemecahan masalah yang terdapat dalam LKPD. Selama kegiatan diskusi berlangsung, pendidik memantau jalannya diskusi, memberikan bimbingan serta motivasi agar peserta didik aktif terlibat dalam kegiatan pemecahan masalah di kelompok masing-masing. Hal ini sesuai dengan yang dipaparkan Anita yakni pendidik memberikan motivasi agar peserta didik aktif berdiskusi karena hasil pemikiran beberapa peserta didik akan lebih baik daripada hasil pemikian satu peserta didik saja (Apriyanti, 2010). Tahap ini dapat meningkatkan kemampuan pemecahan masalah matematis peserta didik pada tahap melaksanakan rencana pemecahan masalah di mana, peserta didik menyelesaikan soal-soal latihan pemecahan masalah yang disajikan pada LKPD, dan tahap ini juga menumbuhkan sikap percaya diri dan tanggung jawab peserta didik.

Tahap Evaluate, pada tahap ini peserta didik dievaluasi pemahaman dan keterampilannya dengan mengerjakan kuis secara individu. Tahap ini, pendidik melihat sejauh mana kemampuan peserta didik dalam menyelesaikan permasalahan yang disajikan pada LKPD di mana soal tersebut merupakan soal-soal pemecahan masalah. Peserta didik dituntut menyelesaikan permasalahan tersebut 
secara individu. Menurut pendapat Bruner bahwa berusaha sendiri untuk mencari pemecahan masalah serta pengetahuan yang menyertainya, menghasilkan pengetahuan yang benar-benar bermakna (Trianto, 2012). Tahap ini, dapat meningkatkan kemampuan pemecahan masalah peserta didik pada indikator melakukan pengecekan kembali dan juga membantu menumbuhkan sikap percaya diri dan mampu bekerja sendiri. Peserta didik dituntut untuk mampu mengerjakan sendiri soal-soal yang diberikan, dan tidak bertanya pada orang lain dalam penyelesaiannya, hal ini sesuai dengan pendapat Uno bahwa kemandirian sebagai kemampuan untuk mengarahkan dan mengendalikan diri dalam berpikir dan bertindak, serta tidak merasa bergantung pada orang lain secara emosional. Pada intinya, orang yang mandiri itu mampu bekerja sendiri dan tidak bergantung kepada orang lain (Tresnaningsih dkk., 2019).

Pada fase Evaluate ini terjadi siklus berulang. Jika peserta didik belum benar menjawab kuis, maka peserta didik diberi kesempatan untuk kembali pada tahap explain untuk mengulangi memahami materi. Kemudian dilajutkan ke tahap elaborate, peserta didik kembali memahami latihan yang sudah dibahas dan menanyakan pada pendidik maupun peserta didik yang benar menjawab kuis jika ada hal yang belum dipahami dari materi maupun latihan. Kemudian kembali mengerjakan kuis. Siklus tersebut akan terus berulang hingga peserta didik mampu menjawab kuis yang diberikan dengan benar. Jika siklus berulang telah selesai maka peserta didik melanjutkan pada tahap extend.

Fase Extend, pada Fase ini, peserta didik mengerjakan soal-soal perluasan materi secara individu dan terakhir pendidik dan peserta didik mendiskusikan soal tersebut. Dengan kegiatan pada tahap ini peserta didik dapat mengecek kembali langkah-langkah yang telah dilakukan serta menginterpretasikan penyelesaian yang telah diperoleh pada tahap sebelumnya. Pada tahap ini, peserta didik diasah untuk memiliki sikap percaya diri dan mampu bekerja sendiri.

Hasil penelitian ini, juga sesuai dengan penelitian yang dilakukan oleh Silvia Fitriani, tentang pengaruh penerapan model pembelajaran Learning Cycle $7 E$ terhadap kemampuan pemecahan masalah matematis peserta didik kelas XI SMAN 2 Painan. Pada penelitian ini Silvia Fitriani menemukan bahwa kemampuan pemecahan masalah matematis peserta didik yang menerapkan model pemelajaran Learning Cycle $7 E$, lebih tinggi dari pada yang belajar dengan pembelajaran langsung.

Hal lain juga ditemukan pada penelitian Susi Susanti, yang meneliti tentang "Pengaruh Model Pembelajaran Learning Cycle $7 E$ Terhadap Kemampuan Pemecahan Masalah Matematika Bagi Siswa Kelas X MIA SMA Kristen Satya Wacana Salatiga". Mengungkapkan bahwa kemampuan pemecahan masalah peserta didik yang mengikuti pembelajaran menggunakan Learning Cycle $7 E$ lebih baik daripada kemampuan pemecahan matematika peserta didik dengan pembelajaran konvesional di kelas X MIA SMA Kristen Satya Wacana Salatiga.

\section{KESIMPULAN}


1. Kemampuan pemecahan masalah matematis peserta didik yang belajar melalui model pembelajaran Learning Cycle $7 E$ lebih tinggi dari pada kemampuan pemecahan masalah matematis peserta didik yang belajar dengan pembelajaran biasa di kelas VIII MTsN 3 Solok Selatan Tahun Pelajaran 2020/2021 pada selang kepercayaan 95\%, dengan $\alpha=0,05$.

2. Self-Regulated Learning (kemandirian belajar) matematika peserta didik yang belajar dengan model pembelajaran Learning Cycle 7E di kelas VIII MTsN 3 Solok Selatan mendapatkan kriteria kemandirian belajar dengan persentase $80,76 \%$ yang berada pada kategori baik.

\section{UCAPAN TERIMA KASIH}

Segala puji bagi Allah SWT. Peneliti ucapkan terima kasih kepada semua pihak yang telah membantu hingga penelitian ini dapat terselesaikan. Terima kasih kepada kedua orang tua peneliti atas semua doa' dan dukungan baik moril maupun meteril. Terima kasih kepada Kepala Sekolah dan majelis guru MTsN 3 Solok Selatan, atas izin dan dukungannya hingga penelitian ini selesai. Terima kasih kepada dosen Pembimbing Ibu Dr. Rivdya Eliza dan Ibu Nita Putri Utami, M.Pd atas arahan dan bimbingannya dalam penelitian ini.

\section{REFERENSI}

Af-idah, N. Z., \& Suhendar, U. (2020). Analisis Kemampuan Pemecahan Masalah Siswa Berdasarkan Teori APOS Saat Diterapkan Program Belajar Dari Rumah. 4(2).

Apriyanti. (2010). Penerapan Model Learning Cycle "5e" Dalam Upaya Meningkatkan Kemampuan Pemecahan Masalah Matematika Siswa Smp N 2 Sanden Kelas VIII Pada Pokok Bahasan Prisma Dan Limas. FMIPA UNY.

Darr, C., \& Fisher, J. (2015). Self-regulated learning in mathematics classes. 44-49.

Hafiziani Eka Putri, Idat Muqodas, Mukhamad Ady Wahyudy, Afif Abdulloh, Ayu Shandra Sasqia, \& L. A. N. A. (2020). Kemampuan-Kemampuan Matematis dan Pengembangan Instrumennya. UPI Sumedang Press.

Hewi, L., \& Shaleh, M. (2020). Refleksi Hasil PISA (The Programme for International Student Assesment): Upaya Perbaikan Bertumpu Pada Pendidikan Anak Usia Dini). Universitas Hamzanwadi, 4(01), 30-41.

Khashan, K. (2016). The Effectiveness of using the 7E's learning cycle on the immediate and delayed mathematics achievement and the longitudinal impact of learning among preparatory year students at King Saud University. 7(36).

Lesi Istiqomah, \& Husen Windayana. (2017). Penerapan Model Learning Cycle7E Berbasis Joyful Learn Terhadap Kemampuan Pemecahan Masalah Matematis Siswa. Universitas Pendidikan Indonesia, 5(1).

Maryani, I. (2018). Pendekatan Scientific dalam Pembelajaran di Sekolah Dasar: Teori dan Praktik. Grup Penerbitan CV Budi Utama. 
Mulana, Hanifah, Sujana, \& Gusrayani. (2018). Ragam Model Pembelajaran di Sekolah Dasar. UPI Sumedang Press.

Sepriyanti, N. (2016). Pembelajaran Kalkulus Kontekstual Suatu Modifikasi Model. PT Raja Grafindo Persada.

Shoimin, A. (2014). 68 Model Pembelajaran Inovatif dalam Kurikulum 2013. Ar-Ruzz Media.

Suherman, E. (2003). Strategi Pembelajaran Matematika Kontemporer. FMIPA UPI.

Sumarmo, U. (2004). Kemandirian Belajar, Apa, Mengapa dan Bagaimana Dikembangkan Kemampuan Intelektual Tingkat Tinggi Siswa Sekolah Dasar.

Tresnaningsih, F., Dina Pratiwi Dwi Santi, \& Suminarsih, E. (2019). Kemandirian Belajar Siswa Kelas III SDN Karang Jalak I Dalam Pembelajaran Tematik. 6(2), 51-59.

Trianto. (2012). Model-Model Pembelajaran Inovatif Berorientasi Konstruktivitis. Prestasi Pustaka.

Unaenah, E., \& Rahmah, N. (2019). Pengaruh Model Learning Cycle Terhadap Kemampuan Berpikir Kritis Matematika Peserta didik Kelas V Sekolah Dasar. 5(2), 40-44.

Zamnah, L. N. (2019). Hubungan antara Kemampuan Pemecahan Masalah Matematis denagn SelfEfficacy. Universitas Galuh, 7(2). 